Research Article

\title{
Determination of Sorbic Acid in Cheese Samples by Rapid HPLC-DAD Method
}

\author{
Ayşe Özdemir, ${ }^{1}$ Senem Şanlı ${ }^{D},{ }^{2}$ Barış Sardoğan, ${ }^{3}$ and Seyfi Sardoğan ${ }^{4}$ \\ ${ }^{1}$ Division of Biochemistry, School of Medicine, Uşak University, 64100 Ușak, Turkey \\ ${ }^{2}$ Department of Chemistry, Faculty of Science and Arts, Usak University, Uşak, Turkey \\ ${ }^{3}$ İzmir Kavram Vocational College of Higher Education, İmir, Turkey \\ ${ }^{4}$ Department of Food Engineering, Graduate School of Natural and Applied Sciences, Usak University, Uşak, Turkey \\ Correspondence should be addressed to Senem Şanll; senem.sanli@usak.edu.tr
}

Received 9 September 2019; Revised 19 November 2019; Accepted 7 December 2019; Published 23 January 2020

Academic Editor: Kevin Honeychurch

Copyright (c 2020 Ayşe Özdemir et al. This is an open access article distributed under the Creative Commons Attribution License, which permits unrestricted use, distribution, and reproduction in any medium, provided the original work is properly cited.

\begin{abstract}
The sorbic acid and its salts have been widely used in the food industries for many years as important food preservatives in order to inhibit the growth of various bacteria, yeasts, and fungi in acidic media. The health effects have led to limitation on the concentrations that can be used in food. Because of that, the analytical determination of these preservatives is important for consumer interest and protection. The purpose of this study is to determine the concentration of sorbic acid in cheese samples by using HPLC. For HPLC analysis, an X-Terra RP-18 $(150 \times 4.60 \mathrm{~mm}$ i.d. $\times 5 \mu \mathrm{m})$ column was selected as the stationary phase at $25^{\circ} \mathrm{C}$. Analysis time is about 3 minutes. The developed method was applied to 10 different cheese samples collected from the Turkish market. The levels of sorbic acid in the analyzed samples were between $21.3 \mathrm{mg} / \mathrm{kg}$ and $511.3 \mathrm{mg} / \mathrm{kg}$.
\end{abstract}

\section{Introduction}

Preservatives have been commonly used as additives in food, cosmetics, and pharmaceutical products. Addition of preservatives prevents the alteration and degradation of the product formulation [1]. Nowadays, this type of preservation is often performed with the use of chemical preservatives, such as sorbic acid and its respective sodium, potassium, and calcium salts due to its high solubility. Practical usage of sorbates includes the protection of human food, animal nutrition, pharmaceuticals, cosmetic products, and packaging materials. Sorbates are used as a food preservative in the application areas of cheese and cheese products, yogurt, and sour cream [2-5].

These compounds are generally used to inhibit yeast and mold growth. Additionally, they are effective against a wide range of bacteria. The highest activity of these compounds is recorded in foods with low $\mathrm{pH}$ value, while they are noneffective in foods at neutral $\mathrm{pH}$ value $[6,7]$. Their solubility in water varies depending on the $\mathrm{pH}$ and temperature of the environment. As the concentration of soluble food components such as sucrose, glucose, and $\mathrm{NaCl}$ increases, the solubility of sorbic acid in water decreases. While the solubility of sorbic acid in water at $25^{\circ} \mathrm{C}$ is $0.16 \%$, the solubility of potassium sorbate under the same conditions is above $50 \%$. Potassium sorbate with a chemical structure of $\mathrm{CH}_{3} \mathrm{CH}=\mathrm{CHCH}=\mathrm{CHCOOK}$ is a white crystalline powder. Its solubility in water is very high, and it has a solubility capacity of $139.2 \mathrm{~g}$ in $100 \mathrm{ml}$ of water. $20 \mathrm{~g}$ dissolves in $1 \mathrm{ml}$ of alcohol at $20^{\circ} \mathrm{C}$ [8]. Sorbates are more soluble in alcohol compared to water.

Sorbic acid can be differently applied in foodstuffs. It can be added directly to the product or sprayed onto the surface, sprinkled in powder form, dipped into food-grade sorbate solutions prepared in certain concentrations, or coated with sorbate packaging materials. High concentration solutions are required for dipping and spray applications [9].

Food additives such as preservatives may cause an allergic or intolerance reaction. As a preservative, sorbic acid is regarded as safe and nontoxic, but using especially in large amounts can potentially lead to allergies. Migraine, a common type of headache, is one of the possible adverse 
health effects of potassium sorbate. Higher than normal levels of potassium in the blood may lead to hyperkalemia [10].

The use of sorbic acid and its salts in processed foods is extremely important. Not using this antimicrobial agent may cause microbial activities that lead to food poisoning [11]. However, there are some limitations in using these preservatives. Fermented products are the foremost food group that have limitations for food additives because of their importance in healthy nutrition, prevention, and curing effects. Turkish Food Codex which is prepared considering scientific truths and conclusions of Codex Alimentarius and in accordance with European Union directives is effective in such applications in Turkey [12].

There are various methods for analysis of sorbic acids in food products, such as ultraviolet (UV) spectroscopy, highperformance liquid chromatography (HPLC), GC, and LCMS/MS [13-22]. The purpose of this study is to determine the concentration of sorbic acid in cheese samples by using HPLC. HPLC detection has become the most widely applied analytical separation technique because of its superior performance and reliability, especially in the pharmaceutical, environmental, forensic, clinical, food, and flavor sciences.

\section{Experimental}

2.1. Chemicals. All chemicals in this study were used without further purification. The standard of sorbic acid was obtained from Sigma-Aldrich (St. Louis, Missouri, USA). HPLC-grade acetonitrile (ACN) and methanol $(\mathrm{MeOH})$ were purchased from Merck. Ultrapure water, with conductivity lower than $0.05 \mu \mathrm{S} / \mathrm{cm}$, was obtained with a Milli-Q system (Millipore, Bedford, MA, USA).

Stock solutions of sorbic acid were prepared by dissolving in water $(50 \mathrm{~mL})$ to make a $100 \mathrm{mg} / \mathrm{L}$ solution. All solutions were protected from light, and all solutions were stored at $4^{\circ} \mathrm{C}$ for short time usage (daily) and at $-20^{\circ} \mathrm{C}$ for long-term usage (between days).

2.2. Apparatus. The HPLC analysis was carried out on an Agilent 1260 series HPLC system with ternary solvent pump, online degasser, automatic injection system, column heater, and multi wavelength detector. UV detection was performed at $250 \mathrm{~nm}$. Analyses were run at a flow rate of $1.0 \mathrm{~mL} \cdot \mathrm{min}^{-1}$. Because of the peak shape and analysis time, an X-Terra RP$18(150 \times 4.60 \mathrm{~mm}$ i.d. $\times 5 \mu \mathrm{m})$ column was selected as stationary phase at $25^{\circ} \mathrm{C} .50 \%(v / v) \mathrm{ACN}$-water containing 0.2 $(v / v)$ glacial acetic acid was used as a mobile phase.

2.3. Preparation of Cheese Samples for HPLC Analysis. Ten commercial cheese samples were purchased from local Turkish markets in Uşak. A cheese sample $(5.00 \pm 0.01 \mathrm{~g})$ was weighed in a conical flask and $20 \mathrm{ml}$ of water was added to this sample. The mixture was stirred for 20 minutes in stomacher and then $35.0 \mathrm{ml}$ of methanol was added to this solution. The volume was made up to $100 \mathrm{ml}$ with deionized water. A portion of the filtrate was filtered through a membrane microfilter of pore size $0.45 \mu \mathrm{m}$ (Minisart RC25 17765 ) and then $0.20 \mu \mathrm{m}$ (Minisart RC25). The resulting filtrate was used for $20 \mu \mathrm{L}$ per injection for chromatographic analysis. The peak area was obtained for each solution on the ordinate against the sorbic acid concentration, in milligrams per liter, on the abscissa.

\section{Results and Discussion}

The use of sorbic acid and its salts in processed foods is extremely important. Not using this antimicrobial agent may cause microbial activities that lead to food poisoning [11]. However, there are some limitations. Fermented products are the foremost food group that have limitations for food additives because of their importance in healthy nutrition, prevention, and curing effects. Turkish Food Codex that is prepared considering scientific truths and conclusions of Codex Alimentarius and in accordance with European Union directives is effective in such applications in Turkey [12].

This paper presents rapid and simple methods for the determination of sorbic acid in 10 cheese samples by UVDAD. The improved HPLC method has a good resolution with a short analysis time. For the determination of sorbic acid in cheese samples, C18 column of $(150 \mathrm{~mm} \times 4.6 \mathrm{~mm})$ dimension and $5 \mu \mathrm{m}$ of particle size was used. The mobile phase used during the analysis was 50\% $(v / v)$ ACN-water containing $0.2(v / v)$ glacial acetic acid. By this chromatographic conditions, analysis time is about three minutes (Figure 1).

The chromatographic process was performed at $250 \mathrm{~nm}$. The requirements for the system suitability are usually designed after the development and validation of the method have been completed. The system suitability test results are given in Table 1.

A set of sorbic acid standards were tested to determine the validation parameters (linearity, range, detection limit, and quantitation limit) [23]. The linearity was calculated by plotting the peak area versus concentration of sorbic acid. Five solutions were prepared with $\quad 1.00 \mu \mathrm{g} \cdot \mathrm{mL}^{-1}, \quad 5.00 \mu \mathrm{g} \cdot \mathrm{mL}^{-1}, \quad 10.0 \mu \mathrm{g} \cdot \mathrm{mL}^{-1}$, $20.0 \mu \mathrm{g} \cdot \mathrm{mL}^{-1}$, and $50.00 \mu \mathrm{g} \cdot \mathrm{mL}^{-1}$ sorbic acid concentration, respectively. Each solution was injected in duplicate. The calibration curves were obtained by linear leastsquares regression. The validation data are reported in Table 2. The method exhibited good linearity based on a correlation coefficient $>0.999$ for sorbic acid. The LOD and LOQ were calculated as $3.3 \mathrm{~s} \cdot \mathrm{m}^{-1}$ and $10 \mathrm{~s} \cdot \mathrm{m}^{-1}$, respectively, where $s$ is the standard deviation of the response and $m$ is the slope of the corresponding calibration curve [24, 25].

Repetitive analyses of standard solutions containing $5-20 \mu \mathrm{g} \mathrm{mL}^{-1}$ sorbic acid were performed to evaluate the precision and reproducibility of the method. Sorbic acid was analyzed in consecutive days with five replicates. Repeatability and reproducibility were characterized by mean recovery and RSD, and the results are summarized in Table 3. As deduced from Table 3 , there was no significant difference for the assay, as tested by within-day (intraday) and 


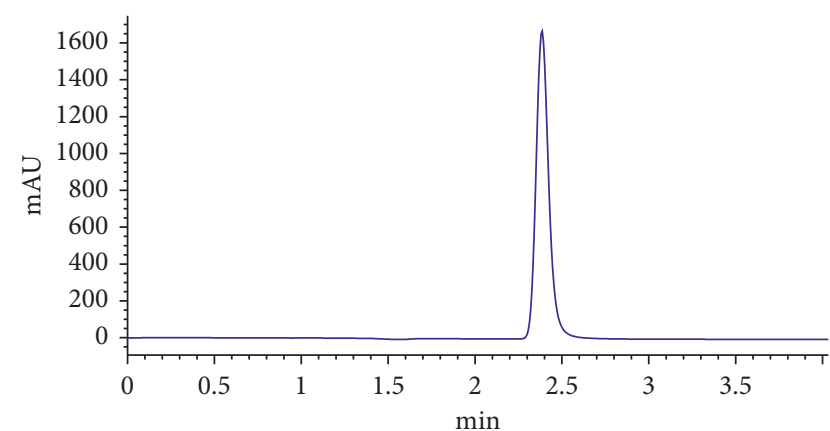

FIgURE 1: Chromatogram of a $50 \mu \mathrm{g} \cdot \mathrm{mL}^{-1}$ sorbic acid standard. The eluent was monitored at $250 \mathrm{~nm}$. Mobile phase consists of ACN : water $(50: 50, v / v)$ containing $0.2(v / v)$ acetic acid. Flow rate is $1 \mathrm{~mL} \cdot \mathrm{min}^{-1}$.

TABLE 1: System suitability parameters of the proposed HPLC method.

\begin{tabular}{lc}
\hline Parameters & DAD \\
\hline Retention time (min) & $2.45 \pm 0.19$ \\
Theoretical plates (N) & $3758 \pm 145$ \\
Tailing factor & $0.97 \pm 0.01$ \\
Peak wavelength & $0.11 \pm 0.02$ \\
\hline
\end{tabular}

TABLE 2: Statistical evaluation of the calibration data of sorbic acid by HPLC-DAD method.

\begin{tabular}{lc}
\hline & Sorbic acid \\
\hline Linearity range $\left(\mu \mathrm{g} \cdot \mathrm{mL}^{-1}\right)$ & $1.00-50.00(n=5)$ \\
Slope & 173.79 \\
Intercept & 36.592 \\
Correlation coefficient $(r)$ & 0.999 \\
Limit of detection $(\mathrm{LOD})\left(\mu \mathrm{g} \cdot \mathrm{mL}^{-1}\right)$ & 0.0018 \\
Limit of quantitation $(\mathrm{LOQ})\left(\mu \mathrm{g} \cdot \mathrm{mL}^{-1}\right)$ & 0.0269 \\
\hline
\end{tabular}

TABle 3: Summary of repeatability (intraday) and reproducibility (interday) precision data for sorbic acid by HPLC-DAD.

\begin{tabular}{lcc}
\hline $\begin{array}{l}\text { Compound concentration } \\
\left(\mu \mathrm{g} \cdot \mathrm{mL}^{-1}\right)\end{array}$ & $\begin{array}{c}\text { Intraday } \\
\text { Mean recovery* } \\
\% \pm \mathrm{RSD} \%\end{array}$ & $\begin{array}{c}\text { Interday } \\
\text { Mean recovery* } \\
\% \pm \mathrm{RSD} \%\end{array}$ \\
\hline 5.0 & $100.115 \pm 0.851$ & $100.025 \pm 0.651$ \\
20.0 & $100.240 \pm 0.112$ & $99.918 \pm 0.498$ \\
\hline
\end{tabular}

${ }^{*}$ Each value is obtained from five experiments $(n=5)$.

between-days (interday) precision. The results supported good precision of the method.

The method was finally tested to evaluate the content of sorbic acid in several kinds of commercial cheeses, and the data are shown in Table 4. As shown in Table 4, in all of the analyzed fresh and kashar cheese samples, the detectable level of sorbic acid was determined. Sorbic acid levels in the cheese samples were found to be lower than the maximum acceptable limits (matured cheese: $1000 \mathrm{mg} \cdot \mathrm{kg}^{-1}$ or $\mathrm{L}^{-1}$ ) of the Turkish Food Codex [26]. In Figure 2, kashar cheese chromatogram is given as an example.
TABLE 4: Sorbic acid content in cheese samples collected from local markets.

\begin{tabular}{lc}
\hline Sample & \\
\hline Kashar cheese 1 & $244.90 \mathrm{mg} / \mathrm{kg}$ \\
Kashar cheese 2 & $271.5 \mathrm{mg} / \mathrm{kg}$ \\
Kashar cheese 3 & $229.05 \mathrm{mg} / \mathrm{kg}$ \\
Kashar cheese 4 & $511.3 \mathrm{mg} / \mathrm{kg}$ \\
Fresh cheese 5 & $255.65 \mathrm{mg} / \mathrm{kg}$ \\
Fresh cheese 6 & $100.10 \mathrm{mg} / \mathrm{kg}$ \\
Fresh cheese 7 & $99.80 \mathrm{mg} / \mathrm{kg}$ \\
Fresh cheese 8 & $72.10 \mathrm{mg} / \mathrm{kg}$ \\
Fresh cheese 9 & $21.30 \mathrm{mg} / \mathrm{kg}$ \\
Fresh cheese 10 & $28.40 \mathrm{mg} / \mathrm{kg}$ \\
\hline
\end{tabular}

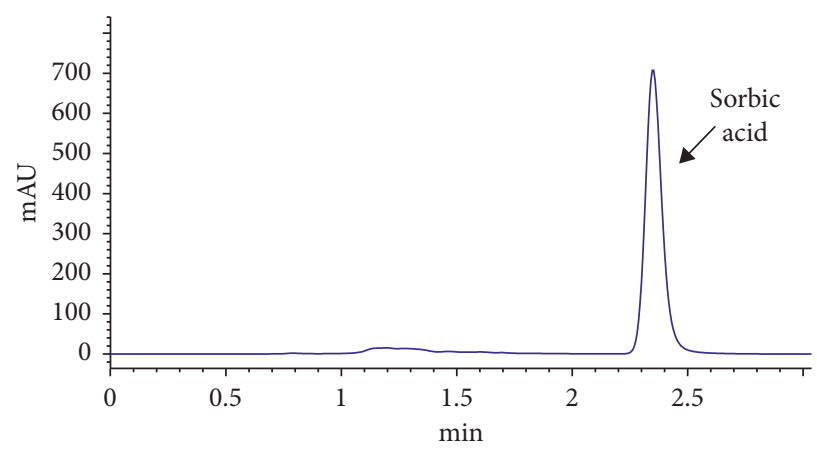

FIgURE 2: Chromatogram of kashar cheese samples.

For the accuracy defined by developed method, known amount of sorbic acid was spiked to the cheese sample and analyzed by the developed method. The study was done at $5 \mathrm{mg} / \mathrm{kg}$ and $10 \mathrm{mg} / \mathrm{kg}$ of test concentration levels. Recovery $\%$ was determined on $n=10$ analyzed samples for each spiking level. The results were found to be 97.5 and 98.1 with low level of RSD values at 0.314 and 0.210 , respectively. Sufficient precision and accuracy could be achieved by this developed method for analysis of cheese samples. The high recovery values obtained show that the method is not affected by the matrix effects in cheese samples.

In the literature, the HPLC method was used for the determination of benzoic acid, sorbic acid, methylparaben, and propylparaben in foodstuffs by Saad et al. [13]. Analysis time for the separation is about 20 minutes, and LOD and LOQ values are 0.1 and $0.3 \mathrm{mgL}^{-1}$, respectively. PetanovskaIlievska et al. [14] reported an LOD of $0.003 \mathrm{mgL}^{-1}$ with the analysis time of 5 minutes. The HPLC method of Zor et al. [15] reported that LOD and LOQ for sorbic acid were 0.082 and $0.271 \mu \mathrm{g} \cdot \mathrm{mL}^{-1}$, respectively. The method described above provides a combination of faster analysis time and improved limits of detection.

\section{Conclusions}

Sorbic acid is widely used in milk products in Turkey. Therefore, the use of sorbic acid by dairy companies should be supervised by the Turkish public health authorities.

In this study, a novel and fast HPLC method for the determination of sorbic acid in 10 commercial cheese 
samples was developed with good accuracy and precision. The analysis is completed in about 3 minutes.

High recovery values indicate that the method is independent of the detrimental effects of additives commonly used in cheese samples. This study has lower detection limit and higher recovery values compared with literature data.

\section{Data Availability}

The data used to support the findings of this study are included within the article.

\section{Conflicts of Interest}

The authors declare that there are no conflicts of interest regarding the publication of this paper.

\section{References}

[1] C. Boukarim, S. A. Jaoude, R. Bahnam, R. Barada, and S. Kyriacos, "Preservatives in liquid pharmaceutical preparations," The Journal of Applied Research, vol. 9, no. 1 and 2, pp. 14-17, 2009.

[2] S. Çakmakçı and İ. Çelik, "Gıda katkı maddeleri," in Ders Notu, No: 164, Atatürk Üniv. Ziraat Fak, Erzurum, Turkey, 1995.

[3] S. Marín, M. Abellana, M. Rubinat, V. Sanchis, and A. J. Ramos, "Efficacy of sorbates on the control of the growth of Eurotium species in bakery products with near neutral $\mathrm{pH}$," International Journal of Food Microbiology, vol. 87, no. 3, pp. 251-258, 2003.

[4] Ö. F. Sağlam, Türk Gıda Mevzuatı, AB Ofset, Ankara, Turkey, 1999.

[5] T. C. Resmi Gazete, Gıda Katkı Maddeleri Yönetmeliği, Başbakanlık Basımevi, Ankara, Turkey, 1990.

[6] S. A. V. Tfouni and M. C. F. Toledo, "Determination of benzoic and sorbic acids in Brazilian food," Food Control, vol. 13, no. 2, pp. 117-123, 2002.

[7] P. Qi, H. Hong, X. Liang, and D. Liu, "Assessment of benzoic acid levels in milk in China," Food Control, vol. 20, no. 4, pp. 414-418, 2009.

[8] A. H. Dinçoğlu, "Use of sorbic acid and their salt in milk and milk products," Doğu Anadolu Bölgesi Araştırmaları, vol. 4, no. 1, pp. 77-83, 2005.

[9] M. Kıvanç, "Gıda koruyucusu olarak sorbik asit ve tuzları: I. Genel özellikleri,” Gıda, vol. 14, no. 5, pp. 315-320, 1989.

[10] https://medlineplus.gov/ency/article/000709.htm.

[11] I. M. P. L. V. O. Ferreira, E. Mendes, P. Brito, and M. A. Ferreira, "Simultaneous determination of benzoic and sorbic acids in quince jam by HPLC," Food Research International, vol. 33, no. 2, pp. 113-117, 2000.

[12] “T. R. Ministry of agriculture and rural affair," 2005, http:// www.tarim.gov.tr.

[13] B. Saad, M. F. Bari, M. I. Saleh, K. Ahmad, and M. K. M. Talib, "Simultaneous determination of preservatives (benzoic acid, sorbic acid, methylparaben and propylparaben) in foodstuffs using high-performance liquid chromatography," Journal of Chromatography A, vol. 1073, no. 1-2, pp. 393-397, 2005.

[14] B. Petanovska-Ilievska, L. Velkoska-Markovska, and M. S. Jankulovska, "Development of reverse-phase highperformance liquid chromatography method for simultaneous determination of sodium benzoate and potassium sorbate in beverages," Acta Chromatographica, vol. 29, no. 3, pp. 345-358, 2017.

[15] Ş. D. Zor, B. Aşçı, Ö. A. Dönmez, and D. Y. Küçükkaraca, "Simultaneous determination of potassium sorbate, sodium benzoate, quinoline yellow and sunset yellow in lemonades and lemon sauces by HPLC using experimental design," Journal of Chromatographic Science, vol. 54, no. 6, pp. 952957, 2016.

[16] C. Dong, Y. Mei, and L. Chen, "Simultaneous determination of sorbic and benzoic acids in food dressing by headspace solid-phase microextraction and gas chromatography," Journal of Chromatography A, vol. 1117, no. 1, pp. 109-114, 2006.

[17] C. De Luca, S. Passi, and E. Quattrucci, "Simultaneous determination of sorbic acid, benzoic acid and parabens in foods: a new gas chromatography-mass spectrometry technique adopted in a survey on Italian foods and beverages," Food Additives and Contaminants, vol. 12, no. 1, pp. 1-7, 1995.

[18] A. C. Gören, G. Bilsel, A. Şimşek et al., "HPLC and LC-MS/ MS methods for determination of sodium benzoate and potassium sorbate in food and beverages: performances of local accredited laboratories via proficiency tests in Turkey," Food Chemistry, vol. 175, pp. 273-279, 2015.

[19] M. Amirpour, A. Arman, A. Yolmeh, M. Akbari Azam, and Z. Moradi-Khatoonabadi, "Sodium benzoate and potassium sorbate preservatives in food stuffs in Iran," Food Additives \& Contaminants: Part B, vol. 8, no. 2, pp. 142-148, 2015.

[20] F. Fuselli, C. Guarino, A. La Mantia, L. Longo, A. Faberi, and R. M. Marianella, "Multi-detection of preservatives in cheeses by liquid chromatography-tandem mass spectrometry," Journal of Chromatography B, vol. 906, pp. 9-18, 2012.

[21] C. Guarino, F. Fuselli, A. L. Mantia, and L. Longo, "Development of an RP-HPLC method for the simultaneous determination of benzoic acid, sorbic acid, natamycin and lysozyme in hard and pasta filata cheeses," Food Chemistry, vol. 127, no. 3, pp. 1294-1299, 2011.

[22] N. Koyuncu and V. Uylaser, "Benzoic acid and sorbic acid levels in some dairy products consumed in Turkey," Asian Journal of Chemistry, vol. 21, no. 6, pp. 4091-4098, 2009.

[23] ICH, ICH, Topic Q2A Validation of Analytical Procedures Methodology, Geneva, Switzerland, 2000.

[24] C. M. Riley and T. W. Rosanske, Development and Validation of Analytical Methods, Elsevier, New York, NY, USA, 1996.

[25] M. E. Swartz and I. S. Krull, Analytical Method Development and Validation, Marcel Dekker Inc., New York, NY, USA, 1997.

[26] World Publishing, The Laws of Turkish Food, World Publishing, Istanbul, Turkey, 2003. 